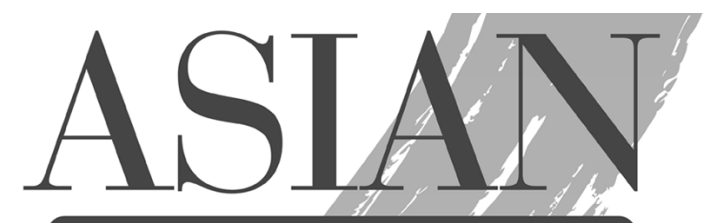

CARDIOVASCULAR \& THORACIC

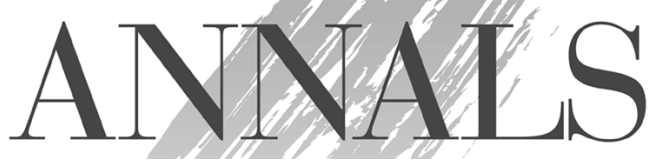

Myocardial Damage Induced by Uncontrolled Reoxygenation

Antonio F Corno, Giuseppina Milano, Michele Samaja and Ludwig K von Segesser Asian Cardiovasc Thorac Ann 2000;8:34-37

This information is current as of February 12, 2010

The online version of this article, along with updated information and services, is located on the World Wide Web at:

http://asianannals.ctsnetjournals.org/cgi/content/full/8/1/34

The Asian Cardiovascular \& Thoracic Annals is the official journal of The Asian Society for Cardiovascular Surgery and affiliated journal of The Association of Thoracic and Cardiovascular Surgeons of Asia. 


\title{
MYOCARDIAL DAMAGE INDUCED BY UNCONTROLLED REOXYGENATION
}

\author{
Antonio F Corno, MD, FRCS, Giuseppina Milano, PhD, \\ Michele Samaja, $P h D^{l}$, Ludwig K von Segesser, $M D$ \\ Department of Cardiovascular Surgery \\ University Hospital of Vaud \\ Lausanne, Switzerland \\ ${ }^{1} S$ Paolo Hospital, University of Milan \\ Milan, Italy
}

\begin{abstract}
To evaluate myocardial impairment induced by uncontrolled reoxygenation, the effects of hypoxia-reoxygenation were compared with ischemia-reperfusion in isolated rat hearts. After stabilization, 2 groups $(\mathrm{n}=8)$ of Langendorff-perfused rat hearts were exposed to 40 minutes of ischemia (10\% of baseline flow) or hypoxia (10\% of baseline oxygen content) followed by a sudden return to baseline conditions (reperfusion or reoxygenation). The $\mathrm{O}_{2}$ content was identical for the two groups during baseline conditions, $\mathrm{O}_{2}$ shortage, and $\mathrm{O}_{2}$ readmission. Metabolic (lactate production) and functional parameters (heart rate, peak systolic pressure, left ventricular developed pressure, maximal contraction and relaxation rates, end-diastolic pressure, coronary perfusion pressure) were recorded at the end of stabilization, after $\mathrm{O}_{2}$ deficiency, and after 2 minutes of reoxygenation. Systolic function was significantly depressed after ischemia ( $\mathrm{p}<0.0001)$ but completely recovered to baseline values after 2 minutes of reperfusion. In contrast, systolic function was less severely depressed after hypoxia but failed to return to baseline after 2 minutes of reoxygenation. Diastolic function, unchanged during ischemiareperfusion, remained significantly impaired during hypoxia-reoxygenation.
\end{abstract}

(Asian Cardiovasc Thorac Ann 2000;8:34-7)

\section{INTRODUCTION}

Surgical repair of cyanotic congenital heart defects is performed under cardiopulmonary bypass (CPB) at an early age with increasing frequency. Postoperative myocardial dysfunction is the major cause of morbidity and mortality despite adequate anatomic correction and it is more severe than after surgery for acquired lesions in adults with normoxic conditions. The main difference in intraoperative management of cyanotic children is the reversal of hypoxemia occurring at the beginning of CPB, preceding the surgical ischemia necessary to perform the intracardiac repair. The conventional method of starting $\mathrm{CPB}$ in cyanotic children is to suddenly raise the oxygen tension (arterial $\mathrm{PO}_{2}$ ) to 300 to $400 \mathrm{~mm} \mathrm{Hg}$ by priming the CPB circuit with hyperoxic fluid. This causes an unintended "reoxygenation phenomenon" that adds to the subsequent intraoperative stress when surgical ischemia is needed for intracardiac repair.

In spite of several experimental observations already reported by our group and others, the role and nature of the reoxygenation phenomenon in clinical practice has yet to be fully established. ${ }^{1-8}$ This experimental study was devised to evaluate the metabolic and functional effects on isolated rat heart of uncontrolled sudden oxygen readmission after a period of oxygen reduction, by

For reprint information contact:

Antonio F Corno, MD, FRCS Tel: 41213142280 Fax: 41213142278 email: antonio.corno@chuv.hospvd.ch University Hospital of Vaud, Department of Cardiovascular Surgery, Rue du Bugnon 46, Lausanne CH1011, Switzerland. 
comparing reoxygenation after hypoxia with reperfusion after ischemia.

\section{MATERIALS AND METHODS}

Male Sprague-Dawley rats (weighing 220 to $280 \mathrm{~g}$ ) fed ad libitum, were anesthetized by intraperitoneal injection of heparinized thiopental sodium $100 \mathrm{mg} \cdot \mathrm{kg}^{-1}$. The hearts were rapidly excised, placed in isotonic saline $\left(20^{\circ} \mathrm{C}\right)$ to facilitate mounting, and immediately perfused via the aorta with Krebs-Henseleit buffer containing $2.5 \mathrm{mM}$ free $\mathrm{Ca}^{2+}$ and $11 \mathrm{mM}$ glucose, $\mathrm{pH} 7.4$, at $37^{\circ} \mathrm{C}$. The ischemic period never exceeded 45 seconds. The perfusion fluid was equilibrated with either $94 \% \mathrm{O}_{2}$ and $6 \% \mathrm{CO}_{2}$ or $10 \% \mathrm{O}_{2}, 6 \% \mathrm{CO}_{2}$, and $84 \% \mathrm{~N}_{2}$, giving a $\mathrm{PO}_{2}$ of 670 or $67 \mathrm{~mm} \mathrm{Hg}$ at constant $\mathrm{PCO}_{2}(43 \mathrm{~mm} \mathrm{Hg})$. A peristaltic pump (Ismatec SA, Labortechnik-Analytik, GlattbruggZurich, Switzerland) delivered the fluid at fixed flow (15 or $\left.1.5 \mathrm{~mL} \cdot \mathrm{min}^{-1}\right)$ to an $8-\mu \mathrm{m}$ pore-size filter $(\mathrm{MSI}$, Westboro, MA, USA), the micro-oxygenator (Dideco, Mirandola, Italy), the pre-heater, and the aortic cannula. All components of the perfusion system were kept at $37^{\circ} \mathrm{C}$ by an external water bath (Bioblok Scientific, Niles, IL, USA). The perfusate was not recirculated. A latex balloon was introduced into the left ventricle through the left atrial appendage and connected to a pressure transducer (model mpc-500; Miller Instruments Inc., Houston, TX, USA) to monitor heart rate (HR), left ventricular end-diastolic pressure (LVEDP), left ventricular developed pressure (LVDP) and maximal rates of heart contraction $\left(+\mathrm{dP} / \mathrm{dt}_{\max }\right)$ and relaxation $\left(-\mathrm{dP} / \mathrm{dt}_{\max }\right)$. A similar pressure transducer was connected above the aortic cannula to monitor coronary perfusion pressure to determine the adequacy of myocardial perfusion. Arterial inflow and coronary sinus return (from an inflow cannula in the pulmonary artery) were collected to measure lactate concentrations. Data were recorded and analyzed by a LabVIEW system 4.1 for PC (National Instruments, Austin, TX, USA).

The hearts $(n=16)$ were stabilized for 30 minutes at a coronary flow rate of $15 \mathrm{~mL} \cdot \mathrm{min}^{-1}$ and $\mathrm{PO}_{2}$ of $670 \mathrm{~mm}$ $\mathrm{Hg}$. The volume of the ventricular balloon, adjusted to achieve LVEDP of $10 \pm 0.1 \mathrm{~mm} \mathrm{Hg}$, was kept constant.
At the end of the stabilization period, the hearts were exposed to either 40 minutes of ischemia by reducing the coronary flow to $1.5 \mathrm{~mL} \cdot \mathrm{min}^{-1}(n=8)$, or 40 minutes of hypoxia by reducing the $\mathrm{PO}_{2}$ to $67 \mathrm{~mm} \mathrm{Hg}$. At the end of ischemia or hypoxia, the hearts were reperfused or reoxygenated for 2 minutes under the same conditions as during stabilization. None of the hearts were paced at any stage. Metabolic and functional measurements were taken at the end of stabilization (baseline), after ischemia or hypoxia, and after the reperfusion or reoxygenation periods. An aliquot of left ventricle was then taken and weighed (wet weight). The sample was placed in a $65^{\circ} \mathrm{C}$ oven and the dry weight was determined after 24 and 48 hours. Myocardial water content was calculated as (wet weight - dry weight)/wet weight $\times 100$.

Data were expressed as mean \pm standard error. To detect significant differences, the two-tailed Student's $t$ test for unpaired observations was used as appropriate. The level of significance was set at $p=0.05$.

\section{RESULTS}

No significant differences were observed between the two groups of hearts at the end of 30 minutes of stabilization, with regard to metabolic and functional parameters (Table 1). The effects of ischemia and reperfusion on systolic function are shown in Figure 1. At the end of ischemia, HR, LVDP, LVDP $\times \mathrm{HR}$, and $+\mathrm{dP} / \mathrm{dt}_{\text {max }}$ were significantly depressed below baseline levels $(p<$ $0.0001)$. However, after 2 minutes of reperfusion, the systolic performance of the ischemic hearts significantly improved compared with the end of ischemia $(p<0.0001)$ and returned to the baseline values. The effects of hypoxia and reoxygenation on systolic function are shown in Figure 2. At the end of hypoxia LVDP, LVDP $\times$ HR, and $+\mathrm{dP} / \mathrm{dt}_{\max }$ were significantly depressed from baseline $(p<0.0001)$ but less $(p<0.05)$ than in the ischemic hearts. After 2 minutes of reoxygenation, the systolic performance of hypoxic hearts had improved $(p<0.05)$ but remained significantly depressed compared to the baseline values $(p<0.0001)$.

The diastolic function (LVEDP) remained unchanged

Table 1. Functional and Metabolic Data at the End of the Stabilization Period

\begin{tabular}{lcc}
\hline Parameter & Ischemic Group $(n=8)$ & Hypoxic Group $(n=8)$ \\
\hline Heart rate $\left(\right.$ beats $\left.\cdot \mathrm{min}^{-1}\right)$ & $267 \pm 6$ & $264 \pm 9$ \\
Peak systolic pressure $(\mathrm{mm} \mathrm{Hg})$ & $117 \pm 5$ & $123 \pm 5$ \\
$+\mathrm{dP} / \mathrm{dt}\left(\mathrm{mm} \mathrm{Hg} \cdot \mathrm{sec}^{-1}\right)$ & $3768 \pm 279$ & $4125 \pm 171$ \\
$-\mathrm{dP} / \mathrm{dt}\left(\mathrm{mm} \mathrm{Hg} \cdot \mathrm{sec}^{-1}\right)$ & $2130 \pm 85$ & $2236 \pm 82$ \\
LVEDP $(\mathrm{mm} \mathrm{Hg})$ & $10.2 \pm 0.1$ & $10.4 \pm 0.1$ \\
Coronary perfusion pressure $(\mathrm{mm} \mathrm{Hg})$ & $65 \pm 3$ & $72 \pm 3$ \\
LVDP $(\mathrm{mm} \mathrm{Hg})$ & $107 \pm 5$ & $112 \pm 5$ \\
LVDP $\times$ heart rate $\left(\mathrm{mm} \mathrm{Hg} \times 10^{-3} \cdot \mathrm{min}^{-1}\right)$ & $28.5 \pm 1.3$ & $29.6 \pm 1.5$ \\
Lactate $\left(\mathrm{mmol} \cdot \mathrm{L}^{-1}\right)$ & $<0.1$ & $<0.1$ \\
\hline
\end{tabular}

$+\mathrm{dP} / \mathrm{dt}=$ rate of contraction, $-\mathrm{dP} / \mathrm{dt}=$ rate of relaxation, $\mathrm{LVDP}=$ left ventricular developed pressure, $\mathrm{LVEDP}=$ left ventricular end-diastolic pressure . 2OOO, VOL. 8, NO. 1 Downloaded from asianannals.ctsnetjournals.org by on February 12,2010 25 LAR \& THORACIC ANNALS 


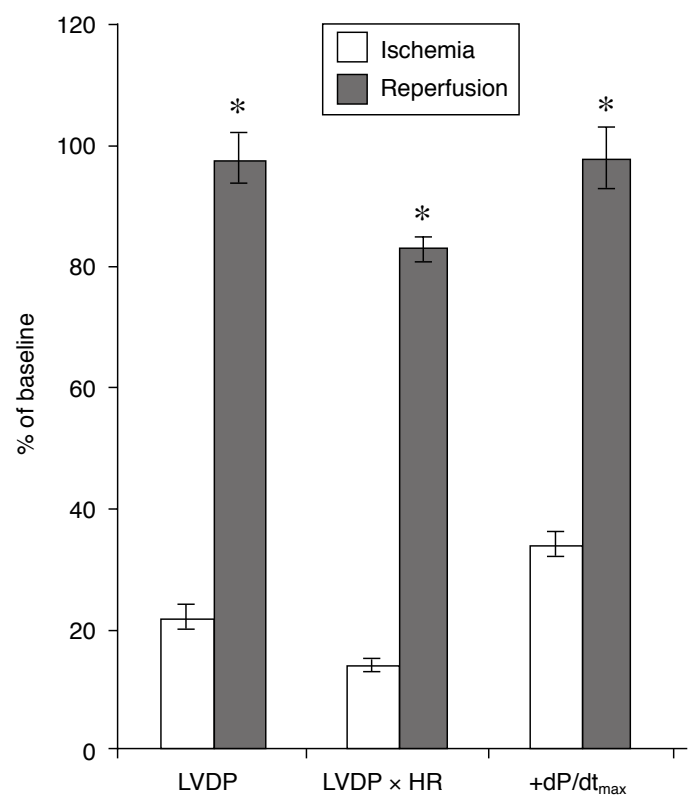

Figure 1. Left ventricular developed pressure (LVPD), left ventricular developed pressure $\times$ heart rate $(\mathrm{LVDP} \times \mathrm{HR})$, and maximal rate of contraction $\left(+\mathrm{dP} / \mathrm{dt}_{\max }\right)$ as percentages of the baseline values, at the end of 40 minutes of ischemia and after 2 minutes of reperfusion. $* p<$ 0.0001 .

compared to the baseline at the end of ischemia and after reperfusion (Figure 3A). In contrast, LVEDP was significantly increased at the end of hypoxia with respect to baseline $(p<0.0001)$ and remained elevated at the end of reoxygenation (Figure $3 \mathrm{~B}$ ).

The lactate concentration in the perfusate was higher at the end of ischemia than at baseline $\left(1.1 \pm 0.1 \mathrm{mmol} \cdot \mathrm{L}^{-1}\right.$ versus $<0.10 \mathrm{mmol} \cdot \mathrm{L}^{-1}$, respectively) and returned to baseline after 2 minutes of reperfusion. At the end of hypoxia, the perfusate lactate concentration was higher than baseline $\left(0.4 \pm 0 \mathrm{mmol} \cdot \mathrm{L}^{-1}\right.$ versus $<0.1 \mathrm{mmol} \cdot \mathrm{L}^{-1}$, respectively) but it was lower than the level found after ischemia. After reoxygenation it returned to baseline, as observed after reperfusion. No significant differences were observed between ischemic and hypoxic hearts with regard to myocardial water content $(80 \% \pm 5 \%$ and $78 \% \pm 3 \%$, respectively).

\section{DISCUSSION}

The negative effects of uncontrolled reoxygenation (reoxygenation phenomenon) on myocardial metabolism and function have been demonstrated previously by both experimental and clinical studies. ${ }^{1-9}$ Since the reoxygenation phenomenon seems to occur in the very early period after oxygen readmission and the previous studies, including ours, evaluated myocardial function and metabolism after a prolonged period of reoxygenation, we decided to analyze the changes during the first 2 minutes of oxygen readmission. This study on isolated perfused rat hearts allowed the following observations: the same degree of oxygen deficit impaired systolic

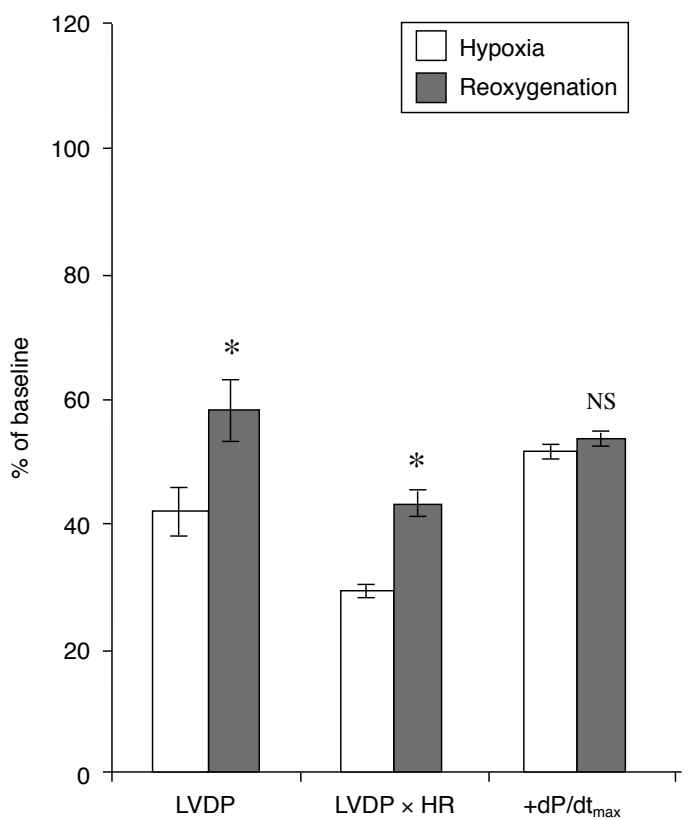

Figure 2. Left ventricular developed pressure (LVPD), left ventricular developed pressure $\times$ heart rate (LVDP $\times$ HR), and maximal rate of contraction $\left(+\mathrm{dP} / \mathrm{dt}_{\max }\right)$ as percentages of the baseline values, at the end of 40 minutes of hypoxia and after 2 minutes of reoxygenation. $* p<0.05$.

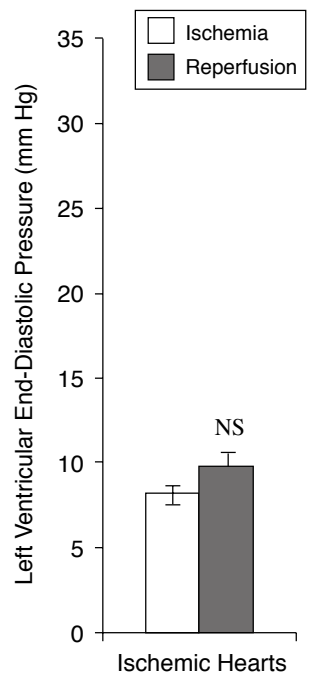

A

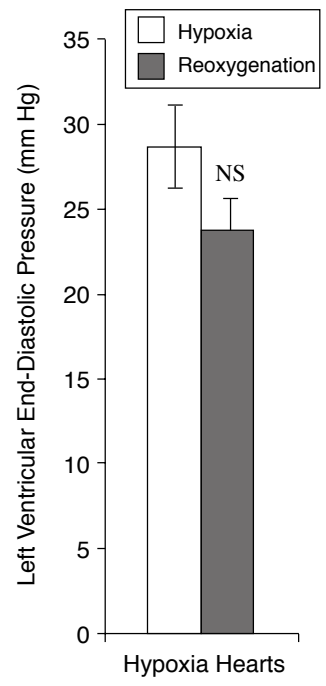

B
Figure 3. Left ventricular end-diastolic pressure (A) after ischemiareperfusion and (B) after hypoxia-reoxygenation. NS = not significant.

function after both ischemia and hypoxia, although to different extents, confirming that anaerobic metabolism did not compensate for reduced oxygen availability, independent of the rate of flow maintained; diastolic function, unaffected by ischemia-reperfusion, remained severely impaired during hypoxia-reoxygenation, possibly due to reduced left ventricular compliance as a result of increased myocardial water content induced by the full flow maintained during hypoxia; and whereas uncontrolled reperfusion provided prompt recovery of ischemic hearts, systolic function after hypoxia remained severely impaired 
on reoxygenation and this might be aggravated by the persisting diastolic dysfunction. These observations confirm the importance of the reoxygenation phenomenon. Experimental studies performed by our group as well as by other researchers, on the negative myocardial effects of acute reoxygenation have shown that controlled reoxygenation, avoiding a sudden rise of arterial $\mathrm{PO}_{2}$ from a low hypoxic level to full oxygenation, reduced the reoxygenation damage. $1,10,11$

We understand the limitations of our current study. Firstly, the effects were evaluated only on isolated hearts and we are aware of the potential effects of reoxygenation on the entire body, particularly the CPB-generation of reactive oxygen intermediates that alter neutrophils, complement, and arachidonic acid metabolism. Secondly, the effect of reoxygenation was assessed after acute hypoxia, whereas children with congenital heart defects suffer from chronic hypoxia. To overcome this limitation, a further study on chronic hypoxia is planned. In addition, the hearts in this study were normal at the outset but children come to surgery after a period of ventricular pressure and/or volume overload with hypertrophic and/or dilated hearts. To overcome this limitation, the same evaluations will be undertaken in hearts with induced hypertrophy and/or dilatation. However, the clinical inference from these experimental observations is that uncontrolled reoxygenation at the start of CBP in cyanotic children should be avoided. In fact, preliminary reports are already available on our experience and that of another group, of controlled reoxygenation in cyanotic children undergoing surgical repair, with encouraging results. ${ }^{12-14}$

\section{ACKNOWLEDGMENT}

We thank the manufacturer, Dideco, for providing specially designed micro-oxygenators for this study.

\section{REFERENCES}

1. Corno AF, Motterlini R, Tarantola M, Samaja M. Reperfusion injury of the hypoxemic heart: role of acute reoxygenation before ischemia. In: Grossi A, Donatelli F, Corno AF, Brodman R, editors. Cardiology and cardiac surgery: current topics. New York: Futura, 1992:379-96.

2. Corno AF, Samaja M. The reoxygenation phenomenon. J Thorac Cardiovasc Surg 1993;105:373-4.
3. Samaja M, Casalini S, Allibardi S, Corno A, Chierchia S. Regulation of bioenergetics in $\mathrm{O}_{2}$-limited isolated rat hearts. J Appl Physiol 1994;77:2530-6.

4. Samaja M, Motterlini R, Allibardi S, Casalini S, Merati G, Corno A, et al. Myocardial metabolism and function in acutely ischemic and hypoxemic isolated rat hearts. J Mol Cell Cardiol 1995;27:1213-8.

5. Buckberg GD. Studies of hypoxemic/reoxygenation injury: linkage between cardiac function and oxidant damage. J Thorac Cardiovasc Surg 1995;110:1164-70.

6. Guarnieri C, Flamigni F, Caldarera CM. Role of oxygen in the cellular damage induced by reoxygenation of hypoxic heart. J Mol Cell Cardiol 1980;12:797-808.

7. Hearse DJ, Humphrey SM, Nayler WG, Slade A, Border D. Ultrastructural damage associated with reoxygenation of the anoxic myocardium. J Mol Cell Cardiol 1975;7: 315-24.

8. Ihnken K, Morita K, Buckberg GD, Matheis G, Sherman MP, Allen BS, et al. Studies of hypoxemic/reoxygenation injury: without aortic clamping. Evidence for reoxygenation damage. J Thorac Cardiovasc Surg 1995;110:1171-81.

9. del Nido PJ, Mickle DAG, Wilson GJ, Benson LN, Weisel $\mathrm{RD}$, Coles JG, et al. Inadequate myocardial protection with cold cardioplegic arrest during repair of tetralogy of Fallot. J Thorac Cardiovasc Surg 1988;95:223-9.

10. Corno AF, Samaja M, Casalini S, Allibardi S. The effects of the rate of reoxygenation on the recovery of hypoxemic hearts. J Thorac Cardiovasc Surg 1995;109:1250-1.

11. Morita K, Ihnken K, Buckberg GD. Studies of hypoxemic/ reoxygenation injury: with aortic clamping. Delay of cardiac reoxygenation damage in the presence of cyanosis: a new concept of controlled cardiac reoxygenation. J Thorac Cardiovasc Surg 1995;110:1265-73.

12. Corno AF, da Cruz E, Lal A, Milella L, Wilson N. "Controlled reoxygenation" for cyanotic patients. In: Imai Y, Momma K, editors. Proceedings of 2nd World Congress of PCCS. New York: Futura, 1998:1127-9.

13. Corno AF, von Segesser LK. Is hypothermia necessary in pediatric cardiac surgery? Eur J Cardio-thorac Surg 1999;15:110-1.

14. Allen BS, Rahman S, Ilbawi MN, Kronon M, Bolling KS, Halldorsson AO, et al. Detrimental effects of cardiopulmonary bypass in cyanotic infants: preventing the reoxygenation injury. Ann Thorac Surg 1997;64:1381-7. 


\section{Myocardial Damage Induced by Uncontrolled Reoxygenation}

Antonio F Corno, Giuseppina Milano, Michele Samaja and Ludwig K von Segesser Asian Cardiovasc Thorac Ann 2000;8:34-37

\section{This information is current as of February 12, 2010}

Updated Information
\& Services
References
Citations
Permissions \& Licensing
Reprints

including high-resolution figures, can be found at:

http://asianannals.ctsnetjournals.org/cgi/content/full/8/1/34

This article cites 8 articles, 4 of which you can access for free at: http://asianannals.ctsnetjournals.org/cgi/content/full/8/1/34\#BIBL

This article has been cited by 2 HighWire-hosted articles: http://asianannals.ctsnetjournals.org/cgi/content/full//8/1/34\#otherar ticles

Requests to reproduce this article in parts (figures, tables) or in its entirety should be submitted via email to: info@asiapex.com

For ordering reprints, please email: info@ asiapex.com

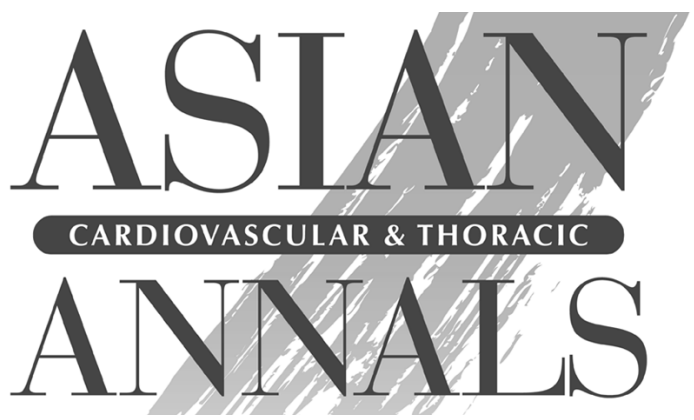

